\title{
Bioaktivitas Ekstrak Kulit Buah Nanas (Ananas comosus (L.) Merr.) dalam Sabun Cuci Piring sebagai Antibakteri terhadap Bakteri Staphylococcus aureus
}

\author{
Urmatul Waznah, Khusna Santika Rahmasari, Wulan Agustin Ningrum, dan Slamet
}

Program Studi Sarjana Farmasi, Fakultas IImu Kesehatan, Universitas Muhammadiyah Pekajangan, Pekalongan, Indonesia

Korespondensi: Urmatul Waznah

Email: urmatul.farmasi@gmail.com

Submitted: 12-11-2021, Revised: 15-12-2021, Accepted: 20-12-2021

\begin{abstract}
ABSTRAK: Kulit buah nanas (Ananas comosus (L.) Merr.) mengandung vitamin C, karotenoid, flavonoid, dan enzim bromelain yang dapat digunakan sebagai antibakteri. Enzim bromelain berfungsi sebagai antiseptik. Tujuan penelitian ini adalah untuk mengetahui bioaktivitas ekstrak kulit buah nanas pada sabun cuci piring sebagai antibakteri terhadap Staphylococcus aureus. Sabun cuci piring ekstrak kulit buah nanas diformulasikan dengan konsentrasi ekstrak yang berbeda yaitu pada 10\% (FI), 20\% (FII), dan 30\% (FIII). Metode yang digunakan untuk uji antibakteri adalah metode difusi sumuran. Hasil pengamatan pada inkubasi selama 24 jam diperoleh rata-rata zona hambat terbesar pada FIII yaitu sebesar 19,3 mm, sedangkan pada FII dan FI masing-masing diperoleh zona hambat sebesar $15 \mathrm{~mm}$ dan $13 \mathrm{~mm}$. Kontrol positif (sabun cuci piring merk SL) menunjukkan adanya zona bening dengan rata-rata diameter zona hambat yaitu 25,3 $\mathrm{mm}$. Formula yang memiliki zona hambat bakteri terbesar adalah FIII. Hasil dari penelitian ini menunjukkan adanya kemampuan kulit buah nanas untuk menghambat pertumbuhan Staphylococcus aureus sehingga dapat digunakan sebagai sabun cuci piring.
\end{abstract}

Kata kunci: antibakteri; ekstrak kulit buah nanas; Staphylococcus aureus

\begin{abstract}
Pineapple peel (Ananas comosus (L.) Merr.) contains vitamin C, carotenoid, flavonoid, and bromelain enzyme which can be used as antibacterial and also as antiseptic. The purpose of this study was to determine the bioactivity of pineapple fruit extracts in dish soap as an antibacterial against Staphylococcus aureus. Pineapple peel extract soap was formulated with different extract concentrations namely in 10\% (FI), 20\% (FII), and 30\% (FIII). The method used for antibacterial test was the diffusion well method. The results showed that FIII exhibited the largest inhibition zone (19.3 mm), meanwhile inhibition zone of FII and FI was $15 \mathrm{~mm}$ and $13 \mathrm{~mm}$, respectively. Positive control (commercial dish soap "SL") showed the presence of a clear zone with an average inhibition zone diameter of 25.3 $\mathrm{mm}$. The formula that has the largest bacterial inhibition zone is FIII. The results of this study indicated the ability of pineapple peel to inhibit the growth of S. aureus, so it can be used as dish soap.
\end{abstract}

Keywords: antibacterial; pineapple peel extract; Staphylococus aureus 


\section{Pendahuluan}

Nanas (Ananas comosus (L.) Merr.) merupakan buah yang mudah dijumpai dan diminati masyarakat. Limbah dari nanas seperti kulit, batang, dan bonggol kurang dimanfaatkan. Kulit buah nanas adalah salah satu bahan yang dibuang begitu saja, padahal bagian tanaman ini mengandung vitamin $\mathrm{C}$, karotenoid, dan flavonoid [1]. Selain itu, terdapat pula kandungan enzim bromelain. Enzim bromelain adalah enzim proteolitik yang ditemukan pada bagian tangkai, batang, daun, buah, ataupun kulit dalam jumlah yang berbeda-beda [2]. Bromelain dapat memutus ikatan protein pada bakteri sehingga dapat menghambat pertumbuhan bakteri. Aktivitas, spesifitas, dan produksi enzim bromelain lebih banyak pada bagian kulit daripada bagian buah dan batang nanas [3]. Zat-zat dalam enzim bromelain dapat mengubah sifat fisika-kimia selaput sel dan dapat menghalangi fungsi normalnya sehingga mampu menghambat serta membunuh bakteri. Enzim bromelain juga berfungsi sebagai antiseptik. Senyawa lain yang terkandung dalam kulit buah nanas seperti flavonoid, saponin, dan tanin dapat digunakan sebagai antibakteri. Flavonoid merupakan senyawa fenol yang berfungsi sebagai antibakteri dan antijamur. Saponin dan tanin merupakan suatu senyawa alami yang banyak terdapat pada tanaman di daerah tropis dan juga bersifat sebagai antibakteri [2]. Enzim bromelain dapat menghambat pertumbuhan bakteri, salah satunya adalah Staphylococus aureus [4].

Staphylococcus aureus merupakan salah satu bakteri penyebab infeksi pada manusia maupun pada hewan [5]. Bakteri ini sering ditemukan sebagai bakteri flora normal pada kulit dan selaput lendir pada manusia. Staphylococcus aureus dapat menginfeksi jaringan atau alat tubuh lain yang menyebabkan timbulnya penyakit dengan tanda-tanda khas seperti nekrosis, peradangan, dan pembentukan abses [6].

Berdasarkan penelitian sebelumnya [3], ekstrak kulit buah nanas mempunyai efek antibakteri yang lebih besar terhadap Staphylococcus aureus daripada ekstrak daging buahnya. Selain itu, penelitian lainnya [7] menyebutkan bahwa ekstrak etanol kulit buah nanas pada sediaan hand sanitizer mampu menghambat pertumbuhan Staphylococcus aureus dan Escherichia coli. Sediaan hand sanitizer ekstrak kulit buah nanas dengan konsentrasi 0,$5 ; 1$; dan 1,5\% masingmasing menghasilkan zona hambat terhadap $E$. coli sebesar 9, 13, dan $15 \mathrm{~mm}$, sedangkan terhadap $S$. aureus menghasilkan zona hambat sebesar 10,15, dan 15,5 mm. Berdasarkan penelitian tersebut, perlu dilakukan penelitian untuk memanfaatkan kulit buah nanas sebagai sabun cuci piring. Tujuan penelitian ini adalah untuk mengetahui bioaktivitas ekstrak kulit buah nanas pada sabun cuci piring sebagai antibakteri terhadap Staphylococcus aureus.

\section{Metode penelitian}

\subsection{Bahan}

Bahan yang digunakan meliputi: kulit buah nanas yang diperoleh dari Kecamatan Belik Kabupaten Pemalang dan telah dideterminasi oleh Laboratorium Jurusan Biologi, FMIPA Universitas Negeri Semarang dengan Nomor surat determinasi 177/UN/37.1.4.5/LT/2018, etanol 96\%, bakteri Staphylococcus aureus, media Nutrient Agar (NA), aquades steril, $\mathrm{NaCl}$ fisiologis 0,9\% dan sabun cuci piring merk SL.

\subsection{Alat}

Alat yang digunakan pada penelitian ini yaitu alat-alat gelas, timbangan analitik (Ohaus), mikropipet (Scilogex), kawat ose, spatula besi, cawan petri, jangka sorong, rak tabung reaksi, inkubator (Mammert), LAF (laminary air flow), autoklaf (Shenan).

\subsection{Pembuatan ekstrak kulit buah nanas}

Kulit buah nanas disortasi basah, lalu dicuci dengan air mengalir, kemudian ditiriskan. Setelah itu dipotong kecil-kecil, diletakkan pada tampah hingga tersebar merata kemudian di- 
angin-anginkan hingga kering. Simplisia kering dihaluskan menggunakan blender, selanjutnya diayak dengan ayakan no 20. Serbuk kulit buah nanas direndam dengan air selama dua hari dengan perbandingan kulit buah nanas : air (1:5) pada suhu kamar sambil sesekali diaduk. Ekstrak kemudian disaring dengan kain flanel dan dimasukkan dalam wadah.

\subsection{Skrining fitokimia}

\subsubsection{Alkaloid}

Sebanyak 0,5 g ekstrak ditambah $1 \mathrm{ml} \mathrm{HCl} 2 \mathrm{~N}$ dan $9 \mathrm{ml}$ akuades, dipanaskan di atas penangas air selama 2 menit, didinginkan, dan disaring. Filtrat yang diperoleh digunakan untuk uji alkaloid. Filtrat dimasukkan ke dalam tabung reaksi masing-masing sebanyak 0,5 ml. Pada masing-masing tabung reaksi ditambahkan 2 tetes pereaksi Meyer dan Dragendorff. Hasil positif alkaloid akan ditunjukkan dengan terjadinya endapan atau kekeruhan [8].

\subsubsection{Flavonoid}

Sejumlah ekstrak ditambah metanol dan dipanaskan di atas penangas air, ditambahkan serbuk Mg 0,1 mg, dan ditambah 5 tetes $\mathrm{HCl}$ pekat. Reaksi positif flavonoid akan ditunjukkan dengan terbentuknya warna merah, kuning, atau jingga [9].

\subsubsection{Fenol}

Sejumlah ekstrak diekstraksi dengan $20 \mathrm{ml}$ etanol 96\%. Diambil $1 \mathrm{ml}$ filtrat, kemudian ditambahkan 2 tetes larutan $\mathrm{FeCl} 3$ 5\%. Reaksi positif fenol ditunjukkan dengan terbentuknya warna hijau atau hijau biru [9].

\subsubsection{Saponin}

Sebanyak 5 g ekstrak dimasukkan ke dalam tabung reaksi, ditambah $10 \mathrm{ml}$ air panas, dan dikocok kuat-kuat selama 10 detik. Hasil positif saponin ditunjukkan dengan terbentuk buih yang banyak selama tidak kurang dari 10 menit setinggi 1-10 cm dan tidak hilang jika dilakukan penambahan 1 tetes $\mathrm{HCl} 2 \mathrm{~N}$ [8].

\subsubsection{Tanin}

Sejumlah 1 g ekstrak dididihkan selama 3 menit dalam $10 \mathrm{ml}$ akuades, lalu didinginkan, dan disaring. Filtrat diencerkan sampai hampir tidak berwarna, lalu ditambahkan 1-2 tetes pereaksi $\mathrm{FeCl}_{3}$. Hasil positif tanin ditunjukkan jika terjadi warna biru kehitaman atau hijau kehitaman [8].

\subsubsection{Terpenoid}

Sejumlah ekstrak ditambahkan pereaksi Liebermann Burchard (asam asetat anhidrat dan asam sulfat pekat). Sampel yang mengandung senyawa golongan terpenoid akan berubah warna membentuk cincin coklat atau violet [10].

\subsection{Formulasi sabun cuci piring}

Sodium Lauril Sulfate (SLS) dilarutkan dalam $50 \mathrm{ml}$ aquades (A). Sejumlah $3 \mathrm{~g} \mathrm{NaCl}$ dilarutkan dalam $10 \mathrm{ml}$ aquades (B). satu g $\mathrm{Na}$ benzoat dilarutkan dalam $10 \mathrm{ml}$ aquades (C). A dimasukkan ke dalam wadah, ditambahkan sejumlah ekstrak kulit buah nanas sesuai pada Tabel 1, dan diaduk hingga homogen. Ke dalam campuran tersebut kemudian ditambahkan $\mathrm{C}$ dan diaduk hingga homogen, kemudian ditambahkan $\mathrm{B}$, terakhir ditambah sisa air dan diaduk hingga homogen. Formula sabun cuci piring ekstrak kulit buah nanas dapat dilihat pada Tabel 1.

\subsection{Uji antibakteri sabun ekstrak kulit buah nanas}

\subsubsection{Pembuatan media nutrient agar (NA)}

Serbuk NA sebanyak 5,2 g dimasukkan ke dalam erlenmeyer, ditambahkan aquades $260 \mathrm{ml}$. Selanjutnya dipanaskan sampai larut sempurna dan ditutup. Setelah itu, media disterilisasi menggunakan autoklaf pada suhu $121^{\circ} \mathrm{C}$ selama 15 menit. Media dibiarkan hingga suhu hangat, dituang ke dalam cawan petri steril, dan dilakukan dalam LAF. Media NA siap untuk digunakan [11].

\subsubsection{Pembuatan suspensi bakteri}

Bakteri S. aureus diambil 1 ose bakteri, dimasukkan ke dalam tabung reaksi yang berisi $10 \mathrm{ml}$ larutan $\mathrm{NaCl}$ fisiologi 0,9\%, dengan biakan murni $S$. aureus di dalam tabung reaksi, dikocok sampai homogen [12]. 
Tabel 1. Formula sabun cuci piring ekstrak kulit buah nanas

\begin{tabular}{llll}
\hline Bahan & Komposisi (\%) & & \\
\cline { 2 - 4 } & FI & FII & FIII \\
\hline Ektrak kulit buah nanas & 10 & 20 & 30 \\
SLS & 18,5 & 18,5 & 18,5 \\
$\mathrm{NaCl}$ & 3 & 3 & 3 \\
$\mathrm{Na}$ benzoat & 1 & 1 & 1 \\
Aquades & Ad 100 & Ad 100 & Ad 100 \\
\hline
\end{tabular}

Tabel 2. Hasil skrining fitokimia ekstrak kulit buah nanas

\begin{tabular}{lll}
\hline Jenis metabolit & Hasil & Keterangan \\
\hline Alkaloid & - & $\begin{array}{l}\text { Tidak terbentuk endapan putih dengan pereaksi Mayer } \\
\text { Tidak terbentuk endapan merah bata dengan pereaksi Dragendorff }\end{array}$ \\
Flavonoid & + & Terbentuk warna merah \\
Fenol & + & Terbentuk warna hijau kehitaman \\
Saponin & - & Tidak terbentuk busa \\
Tanin & + & Terbentuk warna hijau kehitaman \\
Terpenoid & + & Terbentuk warna coklat \\
\hline
\end{tabular}

\subsubsection{Uji antibakteri}

Uji antibakteri dengan metode difusi sumuran dengan cara membuat 5 sumuran pada media yang telah diinokulasikan dengan bakteri $S$. $a u$ reus $200 \mu \mathrm{L}$ untuk FI, FII, dan FIII, kontrol negatif (sabun cuci piring tanpa ekstrak), dan kontrol positif (sabun cuci piring merk SL). Ke dalam sumuran tersebut diisi $1 \mathrm{~g}$ formula sabun cuci piring. Campuran diinkubasi pada suhu $37^{\circ} \mathrm{C}$ selama 18 24 jam dan kemudian diukur diameter zona hambatnya dengan menggunakan jangka sorong [13].

\section{Hasil dan pembahasan}

Skrining fitokimia (Tabel 2) yang telah dilakukan pada ekstrak kulit buah nanas menunjukkan adanya kandungan beberapa senyawa metabolit sekunder. Suatu ekstrak dari bahan alam terdiri dari berbagai macam metabolit sekunder yang dapat diidentifikasi dengan pereaksi yang dapat memberikan ciri khas dari setiap golongan metabolit sekunder tersebut [14]. Berdasarkan hasil skrining fitokimia menunjukkan bahwa ekstrak kulit buah nanas mengandung senyawa flavonoid, fenol, tanin, dan terpenoid [15].

Pada penelitian ini digunakan konsentrasi ekstrak kulit buah nanas 10, 20, dan 30\%. Pemilihan formula ini mengacu pada orientasi yang dilakukan sebelumnya. Basis pembersih yang digunakan adalah campuran surfaktan anionik dan nonionik yaitu Sodium Lauryl Sulfate (SLS). Surfaktan ini menghasilkan basis cuci piring yang memiliki stabilitas busa yang baik serta kemungkinan iritasi yang rendah [16]. Penambahan ekstrak kulit buah nanas dalam dabun cuci piring berfungsi sebagai antibakteri [3] yang diharapkan dapat menjadi solusi dalam mengatasi bakteri pada perlatan rumah tangga. Tujuan pembuatan sabun cuci piring ini adalah membuat sabun cuci piring yang tidak hanya membersihkan sisa kotoran pada peralatan rumah tangga namun juga sebagai antibakteri. Produk sabun cuci piring ekstrak kulit buah nanas dapat dilihat pada Gambar 1.

Karakteristik fisik dari sabun cuci piring ekstrak kulit buah nanas yang digunakan pada penelitian ini telah dilaporkan pada penelitian 


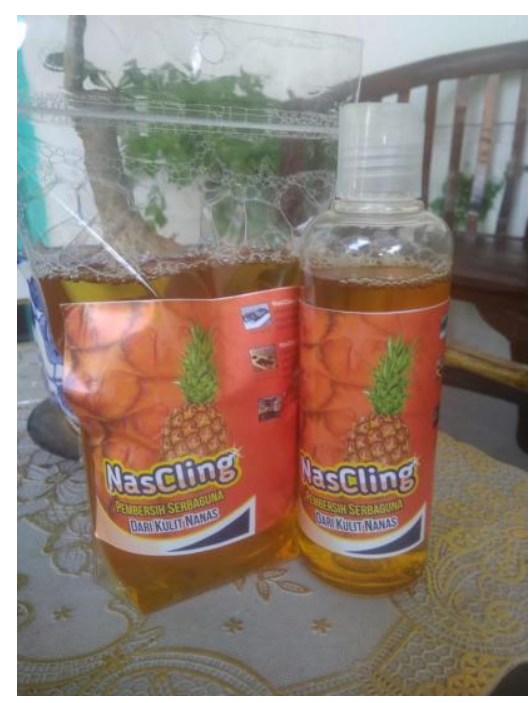

Gambar 1. Sabun cuci piring ekstrak kulit buah nanas

sebelumnya [16]. Hasil uji karakteristik fisik menunjukkan bahwa FII memenuhi persyaratan yang ditetapkan oleh SNI, sehingga perlu dilakukan uji lebih lanjut terhadap aktivitas antibakteri sediaan sabun cuci piring ekstrak kulit buah nanas.

Uji aktivitas antibakteri dilakukan untuk mengetahui apakah sediaan sabun cuci piring ekstrak kulit buah nanas dapat menghambat pertumbuhan $S$. aureus. Hasil pengamatan diameter hambatan sabun cair ekstrak kulit buah nanas terhadap pertumbuhan $S$. aureus setelah masa inkubasi selama 24 jam dapat dilihat pada Gambar 2 dan Tabel 3.

Berdasarkan hasil pengamatan pada inkubasi selama 24 jam diperoleh rata-rata zona hambat terbesar pada FIII dengan konsentrasi ekstrak kulit buah nanas 30\% yaitu sebesar 19,3 mm yang merupakan kategori daya hambat kuat. Pada F II dengan konsentrasi ekstrak kulit buah nanas 20\% diperoleh zona hambat sebesar $15 \mathrm{~mm}$ yang juga termasuk dalam kategori daya hambat kuat. Zona hambat FI dengan konsentrasi ekstrak kulit buah nanas $10 \%$ adalah $13 \mathrm{~mm}$ dengan kategori daya hambat kuat. Hal ini menunjukkan bahwa peningkatan efektifitas dalam menghambat bakteri bersamaan dengan penambahan konsentrasi ekstrak dalam formula. Semakin besar konsentrasi bahan antibakteri, sel-sel mikrooorganisme akan lebih cepat terhambat [17].

Kontrol positif menunjukan adanya zona bening yang begitu luas dengan rata-rata diameter zona hambat yaitu $25,3 \mathrm{~mm}$ yang termasuk dalam kategori daya hambat sangat kuat. Penggunaan kontrol postif bertujuan untuk membandingkan diameter daya hambat sediaan yang beredar di pasar dengan sabun cuci piring ekstrak kulit buah nanas yang dihasilkan [18]. Kontrol negatif tidak terlihat adanya zona bening yang terlihat di sekitar sumuran berarti bahwa basis atau bahan tambahan yang digunakan dalam formula tidak berpengaruh terhadap pertumbuhan $S$. aureus. Penggolongan kekuatan daya antimikroba menurut Davis dan Stout [19], yaitu jika diameter zona bening $<5 \mathrm{~mm}$ dikategorikan sedang, 10-20 mm dikategorikan kuat, dan $>20 \mathrm{~mm}$ dikategorikan sangat kuat. Hasil uji di atas menunjukkan bahwa ekstrak buah nanas mempunyai daya antibakteri kategori kuat terhadap $S$. aureus karena diameter zona hambat yang terbentuk antara 13-19,3 mm.

Adanya zona bening yang terlihat di sekitar sumuran menunjukan bahwa sampel sediaan sabun cuci piring ekstrak kulit buah nanas mengandung senyawa-senyawa yang bersifat sebagai antibakteri diantaranya flavonoid, fenol, terpenoid, dan tanin [3]. Flavonoid di dalam kulit buah nanas mempunyai kemampuan untuk membentuk kompleks dengan protein bakteri melalui ikatan 


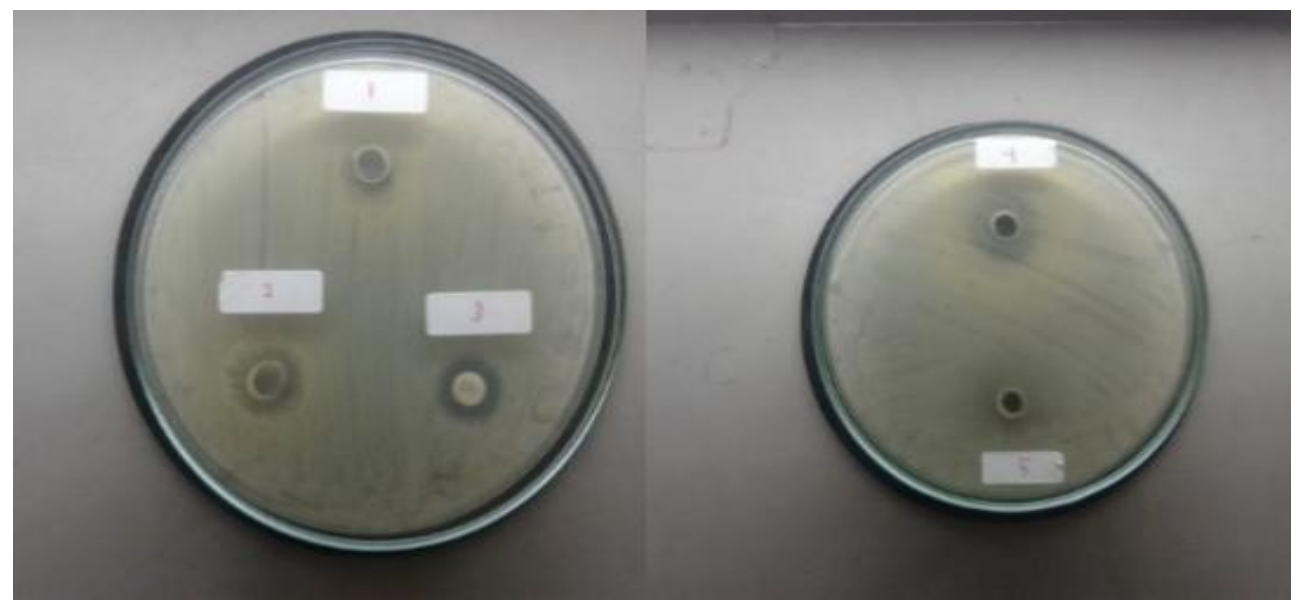

Gambar 2. Hasil pengamatan zona hambat $S$. aureus

1: kontrol negatif, 2: FI, 3: kontrol positif, 4: FII, 5: FIII

Tabel 3. Hasil pengukuran diameter zona hambat sabun cuci piring ekstrak kulit buah nanas terhadap pertumbuhan S. aureus

\begin{tabular}{lllll}
\hline Formula & \multicolumn{4}{l}{ Diameter hambat $\mathbf{( m m )}$} \\
\cline { 2 - 5 } & $\mathbf{1}$ & $\mathbf{2}$ & $\mathbf{3}$ & Rerata \pm SD \\
\hline FI & 15 & 13 & 11 & $13 \pm 2$ \\
FII & 19 & 12 & 14 & $15 \pm 3,61$ \\
FIII & 20 & 18 & 20 & $19,3 \pm 1,15$ \\
Kontrol positif & 26 & 25 & 25 & $25,3 \pm 0,58$ \\
Kontrol negatif & 0 & 0 & 0 & $0 \pm 0$ \\
\hline
\end{tabular}

hidrogen. Keadaan ini dapat menyebabkan struktur dinding sel dan membran sitoplasma bakteri yang mengandung protein menjadi tidak stabil sehingga sel bakteri kehilangan aktivitas biologinya [20]. Saat terjadi kerusakan membran sitoplasma, ion $\mathrm{H}^{+}$dari senyawa fenol dan turunannya (flavonoid) akan menyerang gugus polar sehingga molekul fosfolipida akan terurai menjadi asam karboksilat, asam fosfat, dan gliserol. Hal ini meyebabkan membran sitoplasma akan bocor dan pertumbuhan bakteri akan terhambat bahkan sampai kematian bakteri [21].

Selain flavonoid, kulit buah nanas juga mengandung tanin dan steroid atau terpenoid. Tanin merupakan suatu senyawa penghambat pertumbuhan, sehingga banyak mikroorganisme yang dapat dihambat oleh tanin. Aktivitas tanin sebagai antibakteri dapat terjadi dengan cara menghambat enzim bakteri, menghambat pertumbuhan bakteri dengan cara bereaksi dengan mem- bran sel, dan mengaktivasi enzim-enzim esensial. Senyawa tanin juga akan membentuk kompleks dengan protein melalui interaksi hidrofobik sehingga akan mengalami denaturasi protein dan menyebabkan metabolisme sel terganggu. Mekanisme aktivitas antibakteri dari terpenoid yaitu merusak fraksi lipid membran sitoplasma, mengakibatkan terganggunya proses pembentukan membran atau dinding sel, sehingga mengakibatkan membran atau dinding sel tidak terbentuk atau terbentuk tidak sempurna [21].

\section{Kesimpulan}

Ekstrak kulit buah nanas dalam sediaan sabun cuci piring terbukti mampu menghambat pertumbuhan S. aureus dengan sangat baik. Sediaan sabun cuci piring pada FI, FII, dan FIII menghasilkan zona hambat terhadap S. aureus sebesar 13, 
15, dan 19,3 mm. Formula yang memiliki zona hambat bakteri terbesar adalah F III. Hasil dari penelitian ini menunjukkan adanya kemampuan kulit buah nanas untuk menghambat pertumbuhan $S$. aureus sehingga dapat digunakan sebagai sabun cuci piring.

\section{Daftar pustaka}

1. Hatam SF, Suryanto E, Abidjulu J. Aktivitas Antioksidan Dari Ekstrak Kulit Nanas (Ananas comosus (L) Merr). PHARMACON J Ilm Farm. 2013;2(01):7-12.

2. Putri RMA, Yuanita T, Roelianto M. Daya Anti Bakteri Ekstrak Kulit Nanas (Ananas comosus) Terhadap Pertumbuhan Bakteri Enterococcus faecalis. Conserv Dent J. 2016;6(2):1-6.

3. Husniah I, Gunata AF. Ekstrak Kulit Nanas sebagai Antibakteri. J Penelit Perawat Prof. 2020;2(1):85-90.

4. Manaroinsong A, Abidjulu J, Siagian KV. Uji Daya Hambat Ekstrak Kulit Nanas (Ananas comosus L) Terhadap Bakteri Staphylococcus aureus Secara In Vitro. J Ilm Farm. 2015;4(4):27-33.

5. Septiani S, Dewi EN, Wijayanti I. Aktivitas Antibakteri Ekstrak Lamun (Cymodocea rotundata) terhadap bakteri Staphylococcus aureus Dan Escherichia coli. SAINTEK Perikan Indones J Fish Sci Technol. 2017;13(1):1-6.

6. Walewangko MS, Posangi J, Yamlean PVY. Uji Efek Antibakteri Jamur Endofit Pada Tumbuhan Sereh (Cymbopogon citratus) Pada Bakteri Uji Staphylococcus aureus Dan Escherichia coli. Pharmacon. 2019;8(3):716-24.

7. Rinela A, Rini S, Wijayati N. Hand Sanitizer Ekstrak Kulit Nanas sebagai Antibakteri Staphylococcus aureus dan Escherichia coli. Indones J Chem Sci. 2017;6(1):61-6.

8. Auwal MS, Saka S, Mairiga IA, Sanda KA, Shuaibu A, Ibrahim A. Preliminary phytochemical and elemental analysis of aqueous and fractionated pod extracts of Acacia nilotica (Thorn mimosa). Vet Res forum an Int Q J. 2014;5(2):95-100.

9. Pereira LAR, Pina GO, Silveira CES, Gomes SM, To- ledo JL, Borghetti F. Effects of Eugenia dysenterica L. extracts on roots and gravitropism of Sesamum indicum L. and Raphanus sativus L. Allelopath J. 2017;42(1):3-19.

10. Isnaeni D, Rasyid AUM, Rahmawati. Uji Efektivitas Ekstrak Etanol Daun Upo-upo (Phyllodium pulchellum (L.) Desv.) sebagai Antibakteri terhadap Pertumbuhan Streptococcus viridans dan Streptococcus pyogenes. MPI (Media Pharm Indones). 2021;3(3):138-45.

11. Mazni R, Rahmi, Hendrianto. Sensitivitas Antibakteria Dari Tanaman Caulerpa sp. Dan Enteromorpha sp. Terhadap Bakteri Vibrio alginolyticus A. Simbiosa. 2018;7(1):9-23.

12. Amalia A, Dwiyanti RD, Haitami H. Daya Hambat $\mathrm{NaCl}$ terhadap Pertumbuhan Staphylococcus aureus. Med Lab Technol J. 2016;2(2):42-5.

13. Chandra RA, Yunita R, Wahyuni DD, Anggraini DR. Daya Antibakteri Ekstrak Buah Belimbing Wuluh. Essence Sci Med J. 2015;1:8-18.

14. Wirasti, W. Penetapan Kadar Fenolik Total, Flavonoid Total, dan Uji Aktivitas Antioksidan Ekstrak Daun Benalu Petai (Scurrula atropurpurea Dans.) Beserta Penapisan Fitokimia. J Pharm Med Sci. 2019;4(1):1-5.

15. Reiza I, Rijai L, Mahmudah F. Skrining Fitokimia Ekstrak Etanol Kulit Nanas (Ananas comosus (L.) Merr). Proceeding Mulawarman Pharm Conf. 2019;10:104-8.

16. ajriyah NN, Waznah U, Mugiyanto E. Formulasi Pembersih Serbaguna Berbasis Detergen dari Limbah Kulit Buah Nanas. Jurnal Ilmiah Kesehatan. 2019;12(1):1-6.

17. Wijayati N, Rini ARS, Supartono. Hand Sanitizer with Pineapple Peel Extract as Antibacterial against Staphylococcus aureus and Escherichia coli. Int Conf Math Sci Educ. 2016;2016:40-4.

18. Nofita H, Mugiyanto E, Agustiningrum W. Uji Antibakteri Formula Sediaan Mouthwash Ekstrak Kulit Buah Nanas (Ananas Comosus L . Merr) Terhadap Bakteri Staphylococcus aureus. J Curr Pharm Sci. 2018;2(1):97-103.

19. Davis WW, Stout TR. Disc plate method of microbiological antibiotic assay. I. Factors influencing variability and error. Appl Microbiol. 1971;22(4):659-65. 
20. Widyawati R, Widhowati D, Nadhifa D. Ekstrak Buah Nanas Terhadap Jumlah Total Leukosit Dan Neutrofil Ikan Lele (Clarias batrachus) Yang Diinfeksi Dengan Aeromonas hydrophila. VITEK Bid
Kedokt Hewan. 2020;10:70-7.

21. Saputra 0, Anggraini N. Khasiat Belimbing Wuluh (Averrhoa bilimbi L.) Terhadap Penyembuhan Acne Vulgaris. Majority. 2016;5(1):76-80. 